\title{
Histopathological findings of the kidney Trematoda Paratanaisia spp. (Digenea: Eucotylidae) in cattle egret (Bubulcus ibis)
}

\author{
Achados histopatológicos do Trematoda renal Paratanaisia spp. \\ (Digenea: Eucotylidae) em garça-vaqueira (Bubulcus ibis)
}

Walied Abdo ${ }^{1 *}$; Khaled Sultan ${ }^{2}$

\begin{abstract}
${ }^{1}$ Department of Pathology, Faculty of Veterinary Medicine, Kafrelsheikh University, Kafr El-Sheikh, Egypt
${ }^{2}$ Department of Parasitology, Faculty of Veterinary Medicine, Kafrelsheikh University, Kafr El-Sheikh, Egypt
\end{abstract}

Received November 19, 2012

Accepted April 18, 2013

\begin{abstract}
Paratanaisia spp. was recorded from the right kidney of a cattle egret (Bubulcus ibis) in Kafr Elsheikh governorate, Nile Delta, Egypt. The bird showed marked emaciation and dissipation. Necropsy findings revealed marked enlargement and brownish discoloration of the kidney. Microscopic examination demonstrated marked dilatation of renal tubules with hyperplasia of lining epithelium due to presence of a trematode consistent with Paratanaisia spp. Eggs of this parasite were also noticed deeply within the interstitial tissue, surrounded with mononuclear cell infiltration, thus indicating their pathogenic potential. This result is the first report of trematodes of this genus parasitizing the kidneys of cattle egrets.
\end{abstract}

Keywords: Paratanaisia, kidney, pathology, egret.

\section{Resumo}

Paratanaisia spp. foi registrada no rim direito de um garça-vaqueira (Bubulcus ibis) na regiáo de Kafr Elsheikh, Delta do Nilo, Egito. O pássaro se mostrava bastante emaciado com características consumptivas. Achados de necropsia revelaram acentuado aumento do rim, que estava com descoloração amarronzada. O exame microscópico mostrou importante dilataçáo dos túbulos renais com hiperplasia epitelial devida à presença de um trematódeo consistente com Paratanaisia spp. Ovos deste parasita foram também encontrados na profundidade do tecido intersticial, com infiltração de células mononucleares, indicando assim potencial patogênico. Este resultado é o primeiro relato deste gênero de trematódeo parasitando rins de garça-vaqueiras.

Palavras-chave: Paratanaisia, rim, patologia, garça.

\section{Introduction}

The cattle egret (Bubulcus ibis) is a bird with wide geographic distribution and belongs to the family Ardeidae (SHELDON, 1987). In the delta region of Egypt, several bird species have been recorded, including cattle egrets (GOODMAN et al., 1989). Due to cattle egret overpopulation and extensive spreading in the Egyptian delta, it has been categorized on the black list of invasive species (ESER, 2009).

Paratanaisia spp. (SANTOS, 1934; FREITAS, 1959) are digenetic trematodes that inhabit the kidneys of birds. The geographical distribution of the parasite seems to be restricted to the American continent and the Philippines (TRAVASSOS et al. 1969, FEDYNICH et al., 1996). Infected hosts show mild gross

${ }^{*}$ Corresponding author: Walied Abdo

Department of Pathology, Faculty of Veterinary Medicine,

Kafrelsheikh University, 33516, Kafr El-Sheikh, Egypt

e-mail:waliedsobhy@yahoo.com and microscopic lesions in the infected kidneys (SANTOS, 1934; MENEZES et al., 2001; PINTO et al., 2004), while Luppi et al. (2007) reported granulomatous glomerulonephritis in psittacine birds, caused by $P$. bragai. In this report, we present the first record of pathological features caused by Paratanaisia spp. in the kidney of cattle egrets in Kafr Elsheikh governorate, Northern Nile Delta, Egypt.

A cattle egret (Bubulcus ibis) was sacrificed and subjected to necropsy and histopathological examination. Samples from different organs were immediately fixed in $10 \%$ neutral formalin and then routinely processed for paraffin embedding. Sections of thickness $4 \mu \mathrm{m}$ were stained with hematoxylin and eosin and examined microscopically.

The bird showed emaciation, dissipation and inability to fly. Grossly, most of the organs were within the normal limits, except for the right kidney, which showed enlargement and 
brownish discoloration. Microscopically, a digenetic trematode helminth was observed, consistent with Paratanaisia spp. Brown eggs, some of them containing fully developed embryos, were also noticed. The main parasite burden was within the major collecting tubules, which demonstrated severe dilatation. Some eggs and developed miracidium were found outside the parasites, attached to the lining epithelium, leading to marked hyperplasia and subepithelial mononuclear cell infiltration (Figure 1A). Some of the Paratanaisia eggs were noticed invading subepithelially or deeply into the interstitial renal tissue, which was surrounded with mononuclear inflammatory cell infiltration (Figure 1B). Some of the fully embryonated eggs and developed miracidium were seen to have extended their invasion to be intravascular (Figure 1C). The affected kidney also showed tubular degeneration, intraluminal

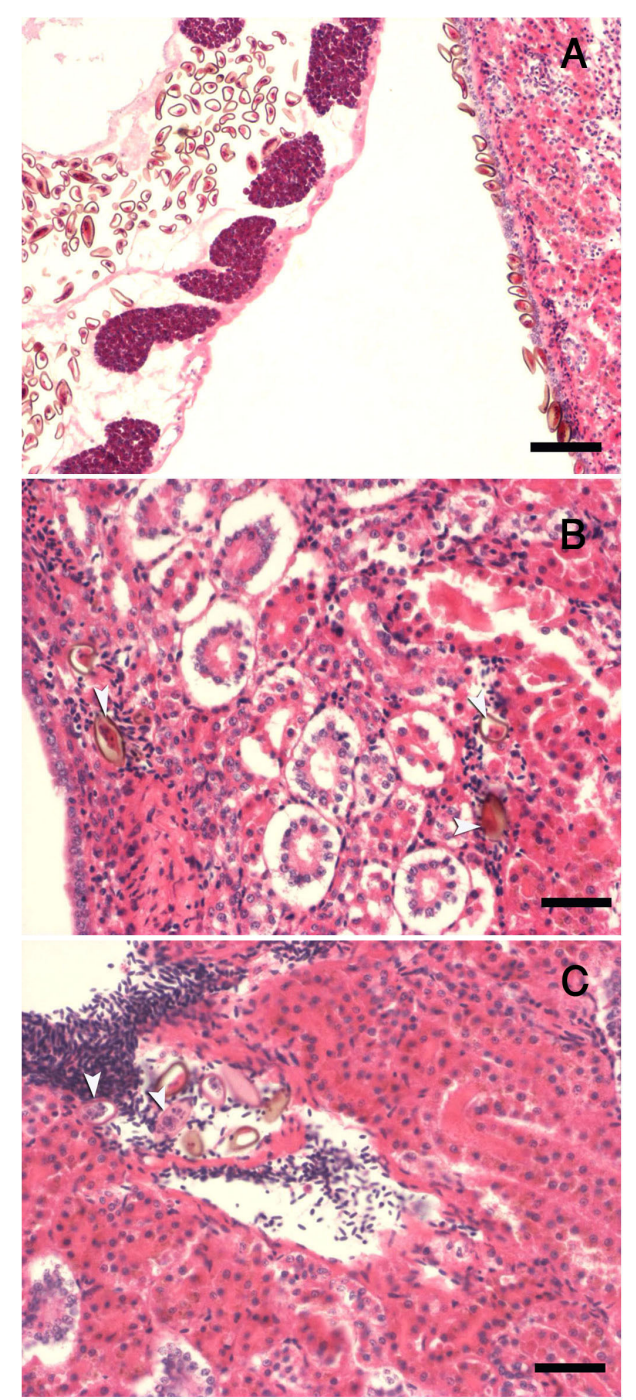

Figure 1. Photomicrographs of the lesions caused by Paratanaisia spp. infection in a cattle egret. A) Cross-section through kidney showing dilated collecting tubules in a part of the trematode section and parasite eggs along the renal tubular epithelium. H\&E, scale bar $=50 \mu \mathrm{m}$; B) Kidney showing presence of parasite eggs interstitially (arrowhead) with mild inflammatory reaction and minor connective tissue proliferation. H\&E, scale bar $=100 \mu \mathrm{m}$; C) Kidney showing intravascular presence of fully embryonated eggs and hatched miracidium leaving empty egg shell (arrowhead). H\&E, scale bar $=100 \mu \mathrm{m}$. eosinophilic hyaline casts and brown hemosiderin pigment within the lining of the tubular epithelium.

It is well known that Paratanaisia spp. were previously reported parasitizing the kidneys of pigeons, chickens, turkeys, spot-winged quails, guinea fowls (MENEZES et al., 2001) and whistling-ducks (FEDYNICH et al., 1996) and that they could be a cause of death in infected birds (ARNIZAUT et al., 1992).

The results represented here indicate that the inflammatory reactions within the affected kidney were primarily due to invading eggs rather than the adult trematodes, which may extend to develop chronic granulomatous nephritis in psittacines, as reported by Luppi et al. (2007). The hyperplasia of the renal tubular epithelium and sub epithelial inflammatory cell infiltration were caused mainly by adult tegument scales and presence of free eggs.

In conclusion, as far as we know, the cattle egret is a new host for Paratanaisia spp. and the pathological findings indicate that their eggs have pathogenic potential.

\section{References}

Arnizaut AB, Hayes GD, Olsen H, Torres JS, Ruiz C, PérezRivera R. An epizootic of Tanaisia bragai in a captive population of Puerto Rican plain pigeon (Columba inornata wetmorei). Ann N Y Acad Sci 1992; 653: 202-205. PMid:1626872. http://dx.doi. org/10.1111/j.1749-6632.1992.tb19647.x

Egypt State of the Environment Report - ESER. Egypt State of the Environment Report 2008. Ministry of State For Environmental Affairs; 2009. Available from: www.Eeaa.gov.eg.

Fedynich AM, Pence DB, Bergan JF. Helminth community structure and pattern in sympatric populations of black-bellied and fulvous whistling-ducks. Can J Zool 1996; 74(12): 2219-2225. http://dx.doi. org/10.1139/z96-252

Freitas JFT. Nota sobre Tanaisia inopina Freitas, 1951 (Trematoda, Eucotylidae). Atas Soc Biol Rio Janeiro 1959; 3:2-4.

Goodman SM, Meininger PL, Baha El-Din SM, Hobbs JJ, Mullie WC. The birds of Egypt. Oxford: Oxford University Press; 1989.

Luppi MM, Melo AL, Motta ROC, Malta MCC, Gardiner CH, Santos RL. Granulomatous nephritis in psittacines associated with parasitism by the trematode Paratanaisia spp. Vet Parasitol 2007; 146(3-4): 363-366. PMid:17418949. http://dx.doi.org/10.1016/j.vetpar.2007.03.011

Menezes RC, Mattos DG Jr, Tortelly R, Muniz-Pereira LC, Pinto RM, Gomes DC. Trematodes of free range reared guinea fowls (Numida meleagris Linnaeus, 1758) in the state of Rio de Janeiro, Brazil: morphology and pathology. Avian Pathol 2001; 30(3): 209-214. PMid:19184902. http://dx.doi.org/10.1080/03079450124448

Pinto RM, Menezes RC, Tortelly R. Systematic and pathologic study of Paratanaisia bragai (Santos, 1934) Freitas, 1959 (Digenea, Eucotylidae) infestation in ruddy ground dove Columbina talpacoti (Temminck, 1811). Arq Bras Med Vet Zootec 2004; 56(4): 472-479. http://dx.doi.org/10.1590/S0102-09352004000400008

Santos V. Monostomose renal das aves domésticas. Rev Dep Nac Prod Animal 1934; 1: 206-211.

Sheldon FH. Phylogeny of herons estimated from DNA-DNA hybridization data. The Auk 1987; 104(1): 97-108. http://dx.doi. org/10.2307/4087238

Travassos L, Freitas JFT, Kohn. A. Trematódeos do Brasil. Mem Inst Oswaldo Cruz 1969; 67: 1-886. PMid:5397756. 